\title{
Cezary Kulesza
}

University of Bialystok, Poland

ORCID: 0000-0003-0509-327X

c.kulesza@uwb.edu.pl

\section{Conflict between the Rights of Victim of a Crime and the Rights of the Accused under the German and Polish Justice System in the Context of the Case-law of European Courts}

\author{
Konflikt między prawami ofiary przestępstwa i oskarżonego \\ w niemieckim i polskim systemie wymiaru sprawiedliwości na tle \\ orzecznictwa Trybunałów Europejskich
}

\section{SUMMARY}

The purpose of this article is to examine conflict between the rights of victims of crimes and the rights of defendants under the German and Polish justice system in the context of the case-law of European courts. The analysis covers two possible occurrences of this conflict: 1) in the cognitive sphere, including proving the defendant's guilt or innocence, and 2) in the decision-making sphere, including initiation of a criminal applying preventive measures, and sentencing. The main thesis of the article is that in the Polish and German criminal process granting the injured parties not only protective rights, but also the status of an active trial party, the risk of this conflict in both of the above-mentioned spheres of the criminal trial is greater than, e.g., in the Anglo-Saxon process where the victim of the crime acts only as a witness. However, the research cited in the article indicates that the extensive codex procedural rights of injured parties as procedural parties (law in books) are not accompanied by their effective use in procedural practice (law in action). Therefore, the protective rights of alleged vulnerable victims, particularly victims of sexual offences, pose a greater threat to the rights of a defendant which constitute the principle of fair trial in Article 6 of the European Convention on Human Rights. Considerations of this article confirm also the thesis that procedural rights of defendants still have priority over victims' rights, which of course results from the inclusion of the former in the human rights catalog contained in the European Convention on Human Rights.

Keywords: conflict of rights; victim of crime; accused; ECtHR; CJEU 


\section{INTRODUCTION}

The rights of victims of crimes are inseparably connected with human rights. As a result of violation of their fundamental rights, victims have the right to justice, which in the context of a criminal process manifests itself as a necessity to grant them the following rights: the right to truth, the right to conviction and punishment of offenders as well as to compensation, and the right to access to the justice system. However, the literature notices conflict between the rights of victims of crimes as human rights and the interests of the state, predominating in administration of justice in criminal cases ${ }^{1}$. The rights and interests of victims of crime can be implemented using two different models: 1) the extension of their rights to participate actively in the process - "model of procedural rights" or 2) widening of the goals and tasks of the police, prosecutors and courts which are targeted at meeting the needs of victims of crime - "model of services". The first model treats the victim as an entity, which should be given broad powers to pursue their interests in criminal proceedings ${ }^{2}$. Service model sees the victim as a special target group for services and activities provided by the procedural agencies. In a certain range, both models can be used together in various combinations. You can, however, be noted that both the German and Polish criminal justice system include main elements of the model of procedural rights, while the English justice system adopted mainly service model ${ }^{3}$. It seems appropriate to assume that the conflict between the rights of victims of crimes and the rights of defendants in a criminal process may be analyzed in two aspects. Firstly, one can examine the possibilities of occurrence of this conflict in two spheres of the criminal trial: 1) in the cognitive sphere, including proving the defendant's guilt or innocence, and 2) in the decision-making sphere, including initiation of criminal proceedings, applying preventive measures and deciding on the subject matter of the proceedings (sentencing). Secondly, an important thing is the relationship between the rights of victims of crimes and the goals and principles of a criminal trial. Of special importance is the problem of restriction of the rights of victims of crimes, resulting from the principle of presumption of innocence and the defendant's right to defence. The choice of the German and Polish justice system results from the fact that under those systems, victims of crimes, holding

1 A. Dearing, Justice for Victims of Crime. Human Dignity as the Foundation of Criminal Justice in Europe, Vienna 2017, pp. 3-9, 341-347.

2 See J.J.M. Van Dijk, Victim's Rights: A Right to Better Services or a Right to Active Participation, [in:] Criminal Law in Action. An Overwiev of Current Issues in Western Societies, eds. J.J.M. Van Dijk, J. Hoffmans, J. Schuttle, S. Stoliwijk, Arnhem 1986, pp. 251-255.

3 Cf. C. Kulesza, Directive 2012/29/EU of 25 October 2012 establishing minimum standards on the rights, support and protection of victims of crime, [in:] Improving Protection of Victims' Rights: Acces to Legal Aid, eds. P. Wiliński, P. Karlik, Poznań 2014, pp. 142-151 and the literature cited thereof. 
the status of injured persons, exercise both the rights of active procedural parties and protective rights. Therefore, it is possible for the conflict under discussion to arise both in the decision and cognitive aspect of criminal proceedings. It should be noted, of course, that the distinction made for the purposes of this article between the two spheres of the process: cognitive and decision making is only conventional, since they are closely related in the process reality. Not only the judgement, but also the decision to take preventive measures requires an appropriate evidence base, which is often co-created by the testimony of the victim of crime. A classic example of a conflict in the cognitive sphere is the conflict between protective measures allowing the vulnerable victim to be heard outside the courtroom and the principle of an adversarial hearing involving the right of the accused to confront witnesses to the prosecution. This right is one of the guarantees of a fair trial provided for in Article 6 (3) letter d of the European Convention on Human Rights (ECHR) and it is one of the guarantees of the right to defence provided for in the $6^{\text {th }}$ Amendment to the US Constitution.

In the decision-making sphere, it should be pointed out that the judgement of the court is influenced by the testimony of each victim as a witness, and e.g. in cases of sexual and domestic violence, they often constitute the only evidence of the accused's guilt. In countries of the common law system, research indicates that in such cases, the behaviour of victims of children and women testifying before the jury, their personal characteristics, emotionality or even appearance is also important for criminal responsibility ${ }^{4}$.

If the victim in a given system of continental law has the status of an auxiliary prosecutor (or in France a civil claimant), he or she may act to the disadvantage of the accused: submit applications for evidence, make final speeches and challenge judgements (and other procedural decisions) to the detriment of the accused.

A particular aspect of conflict in the decision-making process arises when the victim has culpably contributed to the crime by his or her behaviour. It should be noted that during the development of victimology, the concept "precipitation" of a crime by a victim gained special prominence. Attempts to create an overall version of this concept were made by J.J. Gobert, defining a "victim-precipitated"

4 In England, cf. M.R. Kebbell, C.M.E. O'Kelly, E. Gilchrist, Rape Victims' Experiences of Giving Evidence in English Courts: A Survey, "Psychiatry, Psychology and Law" 2007, vol. 14(1), DOI: https://doi.org/10.1375/pplt.14.1.111, pp. 111-118; L. Ellison, V.E. Munro, Better the Devil You Know? 'Real Rape' Stereotypes and the Relevance of a Previous Relationship in (Mock) Juror Deliberations, "International Journal of Evidence \& Proof" 2013, vol. 17(4), DOI: https://doi. org/10.1350/ijep.2013.17.4.433, pp. 299-322. In the USA, cf. A. Cooper, J.A. Quas, K.C. Cleveland, The Emotional Child Witness: Effects on Juror Decision-making, "Behavioral Sciences \& the Law" 2014, vol. 32(6), DOI: https://doi.org/10.1002/bsl.2153, pp. 813-825; P.O. Rerick, T.N. Livingston, D. Davis, Rape and the Jury, [in:] Handbook of Sexual Assault and Sexual Assault Prevention, eds. W. O’Donohue, P.A. Schewe, Cham 2019, pp. 551-565. 
crime as one which would not have taken place without the victim's precipitating action. It refers to a certain perceivable, identifiable action or omission provoking an individual to commit a crime. It is important that J.J. Gobert perceived the symptoms of formal consideration of a victim's "precipitation" by the criminal law: as an element of a crime, an affirmative defence, a causation and a cause of reduced charge, as well as informal impact on the use of pre-trial detention, prosecution and sentencing ${ }^{5}$.

However, while in countries of the common law system, where the victim of crime is not a party to the proceedings but only a witness, the conflict between the protection rights of vulnerable victims and the defendant's right to defence is widely described in the literature ${ }^{6}$, this problem has not been analyzed deeply in continental European legal systems.

The choice of the German and Polish criminal law system is dictated, among other things, by the fact that both legal systems exemplify classic continental law systems based on the principle of legalism of prosecution of crimes (in case of Germany, with certain exclusions). It should be mentioned that the codes of criminal proceedings in both countries do not use the term "crime victim" but "injured person" as a party to the procedure, who may exercise the rights of active participation in a proceeding as an auxiliary or private prosecutor (in Germany, additionally, as a civil plaintiff).

In both systems of continental law analyzed here, the victim as a witness is not only a valuable source of evidence for the procedural authorities, but as a party, he or she pursues his or her own goals in the process (in particular, punishing the accused and restoring the damage suffered), not always consistent with the primary goal of the process, which is to detect the objective truth. The victim, unlike a public prosecutor, is also not obliged to be objective in his or her actions, and both Polish and German law, in accordance with the gravamen institution, allows him or her to appeal against sentences only to the disadvantage of the accused ${ }^{7}$.

5 J.J. Gobert, Victim precipitation, “Columbia Law Review” 1977, vol. 77(4), DOI: https://doi. org/10.2307/1121822, pp. 514-537.

6 In England, see L.C. Hoyano, Striking a Balance between the Rights of Defendants and Vulnerable Witnesses: Will Social Measures Directions Contravene Guarantees of a Fair Trial?, "Criminal Law Review" 2001, no. 12, p. 948 ff.; J.R. Spencer, "Rape shields" and the right to fair trial, "Cambridge Law Journal" 2001, vol. 60(3), DOI: https://doi.org/10.1017/S0008197301241191, pp. 452-455; Z. Carre, The Failure of $R$ v. Killick to Give Victims of Crime a Voice, "North East Law Review" 2016, vol. 4, pp. 62-66. In the USA, see A. Fansher, R.V. del Carmen, Child as Witness: Evaluating State Statutes on the Court's Most Vulnerable Population, "The Children Legal Rights Journal" 2016, vol. 36, pp. 1-26; H.R. Norman, Adult rape victims need protection too: The application of closed circuit television and the exception from maryland v. craig to adult rape victim testimony, "Washburn Law Journal" 2016, vol. 55(3), pp. 701-730.

7 See Article $425 \S 3$ of the Polish Code of Criminal Procedure and $\S 296$ of the German Code of Criminal Proceedings (StPO). 


\section{DIRECTIVE 2012/29/EU OF THE EUROPEAN PARLIAMENT AND OF THE COUNCIL OF 25 OCTOBER $2012^{8}$}

The Directive 2012/29/EU, according to the European law terminology, uses terms "offender" and "victim of crime", specifying that the term "victim" means:

- a natural person who has suffered harm, including physical, mental or emotional harm or economic loss which was directly caused by a criminal offence,

- family members of a person whose death was directly caused by a criminal offence and who have suffered harm as a result of that person's death.

As opposed to the Council Decision 2001/220/JHA, the Directive 2012/29/EU seems to already acknowledge the conflict between an offender and a victim of crime in the preamble, noticing that: "The rights set out in this Directive are without prejudice to the rights of the offender. The term 'offender' refers to a person who has been convicted of a crime. However, for the purposes of this Directive, it also refers to a suspected or accused person before any acknowledgement of guilt or conviction, and it is without prejudice to the presumption of innocence" (recital 12). However, as stated in the Directive implementation report published in December 2017: "The directive seeks to place the victim of a crime at the centre of the criminal justice system, which has traditionally tended to focus on the defendant's rights".

In this context, it can be assumed that the conflict with the defendant's rights may result both from the victims' certain rights of participation in a criminal proceeding, as specified in Chapter 3 of the Directive, namely, the right to review of a decision not to prosecute the defendant (Article 11) and the right to legal aid (Article 13), as well as the protective rights of victims, as specified in Chapter 4 of the Directive ${ }^{10}$. This thesis is confirmed by the Directive authors themselves, expressly stating in the provisions establishing the protective rights of all victims (Articles 18 and 20) as well as of victims with special needs (Articles 23 and 24) that such rights may only be exercised "without prejudice to the rights of the defence". Although the EU legislator does not explain how this phrase is to be interpreted, it is reasonable to assume that in the event of a conflict between the victim's right

8 Directive 2012/29/EU of the European Parliament and of the Council of 25 October 2012 establishing minimum standards on the rights, support and protection of victims of crime, and replacing Council Framework Decision 2001/220/JHA (OJ EU L 315/57), hereinafter: the Directive 2012/29/ EU or Directive.

9 The Victims' Rights Directive 2012/29/EU. European Implementation Assessment. Study, European Parliamentary Research Service, Brussels, December 2017, www.europarl.europa.eu/ RegData/etudes/STUD/2017/611022/EPRS_STU(2017)611022_EN.pdf [access: 20.01.2020], p. 39.

${ }^{10} \mathrm{Cf}$. A. Klip, On Victim 's Rights and Its Impact on the Rights of the Accused, "European Journal of Crime, Criminal Law and Criminal Justice" 2015, vol. 23(3), DOI: https://doi.org/10.1163/1571817423032067, pp. 177-189. 
of protection and the defendant's right of defence, priority should be given to the defendant. It should be noted that the Directive does not in principle refer to the rights of victims to participate actively in the trial (except for the right to legal aid - Article 13). As indicated in the preamble to the Directive, the standards of protection rights provided for in the Directive will be implemented in national systems in different ways, depending on the role of the victim in the relevant justice system: "The role of victims in the criminal justice system and whether they can participate actively in criminal proceedings vary across Member States, depending on the national system, and is determined by one or more of the following criteria: whether the national system provides for a legal status as a party to criminal proceedings; whether the victim is under a legal requirement or is requested to participate actively in criminal proceedings, for example as a witness; and/or whether the victim has a legal entitlement under national law to participate actively in criminal proceedings and is seeking to do so, where the national system does not provide that victims have the legal status of a party to the criminal proceedings. Member States should determine which of those criteria apply to determine the scope of rights set out in this Directive where there are references to the role of the victim in the relevant criminal justice system" (recital 20) ${ }^{11}$. Also, for this reason, it is justified to choose for the purpose of the analysis of the conflict of injured parties' rights the German and Polish systems, which provide for the cumulation of the roles of the victim: as a personal source of evidence (witness) and as an active litigant.

\section{DEFINITION OF AN INJURED PARTY AND THE PRINCIPLE OF PRESUMPTION OF INNOCENCE}

Definition of an injured party may be seen as the first aspect of the conflict between the rights of a defendant and those of a victim of crime. Germany is one of the European countries which do not define the concept of a victim of crime and do not use $i^{12}$. The German Code of Criminal Proceedings (StPO) utilizes the term of injured party (Verletzter), and in a judicial proceedings, the term of an accessory prosecutor, private prosecutor or civil plaintiff. At the same time, the doctrine and case-law assume that an injured party is a person whose legal interest has been directly violated by the alleged act, assuming that such act has actually taken place. An injured party may also be a legal entity, an association, a state organ or another public administration body, a church organ or a religious association,

${ }^{11}$ Cf. The Victims' Rights..., pp. 13-14, 50-51.

${ }^{12}$ Ibidem, pp. 50-51. 
a person harmed by false statements ${ }^{13}$. However, the subjective scope of the injured person in the German procedure does not correspond with the broad concept of the victim of crime, as adopted in the Directive 2012/29/EU. Closest relatives may exercise the right to ancillary complaint in case of an injured person who has died in consequence of an offence, yet they may only do so in case of offences against sexual freedom, life, bodily integrity or personal freedom (§ 395 I and II StPO).

German lawyers indicate the hazards for presumption of innocence of a defendant, resulting from the necessity to implement the rights of active participation and protection rights of an injured person, since presumption of injury in a criminal proceeding may cause aggravation of the defendant's procedural situation and serve as a source of forejudgements concerning their guilt. Such a situation threatens the fair trial standards under Article $6 \mathrm{ECHR}^{14}$. The literature also proposes that, pursuant to the principle of presumption of innocence, a person reporting an offence should not be referred to using the (stigmatizing) label "victim" but as an "informant" or "accuser" Procedure (CCP) of 1997 the provisions of the Code are to ensure that in the course of criminal proceedings legally protected interests of the injured party are taken into consideration while respecting his dignity.

The Polish Code of Criminal Procedure of 1997 does not use the term "victim of a crime" either, but unlike the German system, it contains a definition of an "injured party" in Article 49, which states: "§ 1 . The injured party is either a natural or a legal person, whose legal interest was infringed or threatened by an offence. $\S 2$. The following entity without legal personality may also act in the capacity of the injured party: a state or self-government institution and another organizational entity having legal capacity by virtue of separate provision".

In the context of this substantive-law definitions, referencing the concept of legal interest protected by the Criminal Code, one may point out its advantages compared with the concept of a victim of crime. Despite the reservation of the authors of the Directive 2012/29/EU, as referenced above, it should be noted that using of the term "victim of crime" in fact settles the matter of perpetration of an offence to the detriment of the person under consideration before the court makes a valid decision concerning the defendant's criminal responsibility. The victimological literature

${ }_{13}$ L. Meyer-Gossner, B. Schmitt, Strafprozessordnung. Mit GVG und Nebengesetzen, München 2017, pp. 929-931.

${ }_{14}$ See Stellungnahme des Deutschen Anwaltvereins durch die Task Force „Anwalt für Opferrechte" unter Beteiligung des DAV-Ausschusses Strafrecht zum Referentenentwurf des Bundesministeriums der Justiz und für Verbraucherschutz Entwurf eines Gesetzes zur Stärkung der Opferrechte im Strafverfahren, Berlin 2014, pp. 3-5.

${ }_{15} \mathrm{~B}$. Schünemann, Protection of children and other vulnerable victims against secondary victimisation: Making it easier to testify in Court, "Era Forum" 2009, vol. 9, DOI: https://doi.org/10.1007/ s12027-009-0130-7, p. 395. 
also uses the concept of a "hypothetical victim"16, yet it seems that for the purpose of criminal proceedings the concept of an injured party, as adopted in the Polish law, represents a higher degree of compliance with the principle of presumption of innocence. Under such approach, even far-reaching protection of the injured party's interest in criminal proceedings will not violate the principle of presumption of innocence of a defendant. As shown by the Polish Supreme Court guidelines of 1976 concerning the intensification of protection of the injured party's interests in a court criminal proceeding (OSNKW 1977, no. 1-2, item 2), the recognition of the injured person status of a given entity does not automatically prejudge the fact of perpetration of an offence and causing the damage. Until the perpetration of the alleged act is proven to the defendant, the fact of "injury" remains a specific evidence hypothesis, subject to verification by a procedural authority making the final decision concerning the defendant's criminal responsibility. However, the fact of "hypotheticality" of the injury cannot serve as a basis of restriction of the rights of the injured person as a party to criminal proceedings. Moreover, as evidenced by the 1976 guidelines of the Supreme Court cited above, the fact of contribution of a person harmed by an offence to perpetration thereof should not be relevant for the scope of the injured person's rights in criminal proceedings. Pursuant to the Polish CCP, in case of death of the injured party (before the initiation of the judicial proceeding), the rights to which they would be entitled may be exercised by the closest relatives or persons dependent on the injured person. Similarly, such persons may assume the rights of a deceased auxiliary or private prosecutor. As opposed to the German law, the death of the injured party need not be a consequence of the offence. Therefore, it can be noted that on the one hand, the Polish definition of an injured party pursuant to Article $49 \mathrm{CCP}$ is broader than the concept of a victim of crime (as assumed in acts of European law), since it is not restricted to natural persons, and on the other hand, by using the term of "directness of violation or threat to a legal interest", it excludes some actual victims of crimes from this scope, e.g. in case of offences against the judiciary or documents ${ }^{17}$.

${ }^{16}$ H. Maisch, H. Schueler-Springorum, Procedural Victimology and Its Contribution to Victimological Knowledge, [in:] Victimology: A New Focus, vol. 3: Crimes and Justice, eds. I. Drapkin, E. Viano, Toronto-London 1975, p. 13 ff.

${ }_{17}$ Cf. C. Kulesza, D. Kużelewski, Znaczenie reformy kodeksu postępowania karnego dla efektywności mediacji, [in:] Mediacja w prawie, eds. J. Czapska, M. Szeląg-Dylewski, Kraków 2014, pp. 365-376. 


\section{PROTECTIVE RIGHTS OF INJURED PERSONS VS. THE DEFENDANT'S RIGHTS IN THE COGNITIVE SPHERE OF THE PROCEEDINGS}

The Directive 2012/29/EU provides the right to protection of victims with specific protection needs during criminal proceedings (Articles 23-25 of the Directive). Article 23 stipulates, that without prejudice to the rights of the defence and in accordance with rules of judicial discretion, Member States shall ensure that victims with specific protection needs who benefit from special measures identified as a result of an individual assessment provided for in Article 22 (1), may benefit from the measures provided for in paragraphs 2 and 3 of this Article. A special measure envisaged following the individual assessment shall not be made available if operational or practical constraints make this impossible, or where there is an urgent need to interview the victim and failure to do so could harm the victim or another person or could prejudice the course of the proceedings. Particular attention in the Directive is attached to providing special protection measures for children. Article 24 of the Directive supplements the catalog of measures under Article 23 with special safeguards for children.

Under the German procedure, of essential significance for examination of a minor witness is $\S 241 \mathrm{a}$ StPO, stipulating that examination of a witness below 18 years of age shall be conducted by the president of the panel ${ }^{18}$. Such manner of examination allows the minor to avoid being asked irrelevant or aggressive questions by parties and lawyers. "Cross-examination" (Kreuzverhör), provided for in $\S 239 \mathrm{StPO}$, is precluded in case of a person below 18 years of age. This does not preclude the experts' right to ask questions, since they do not constitute a part of such an examination. Members of the judicial panel, lay judges, the public prosecutor, the defender and the defendant have the right to ask questions indirectly upon the completion of the examination. The president is obliged to ask such questions, excluding improper and irrelevant ones ${ }^{19}$.

The purpose of this protective standard shows that the questions asked must be suited to the child's age and stage of development. Moreover, members of the judicial panel, lay judges, the public prosecutor, the defender and the defendant may apply to the president of the panel for permission to examine of a minor directly, unless this affects the minor's well-being, which is decided by the president of the panel on the basis of free appreciation. Any doubts concerning the admissibility of questions are finally resolved by the court ${ }^{20}$. In the German procedure, it is admissible (recommended) to record the testimonies of witnesses-victims below 18 years

18 See L. Meyer-Gossner, B. Schmitt, op. cit., pp. 1056-1057.

19 C. Gorf, [in:] Strafprozessordnung. Mit GVG und Nebengesetzen. Kommentar, ed. J.P. Graf, München 2010, pp. 907-909.

${ }^{20}$ L. Meyer-Gossner, B. Schmitt, op. cit., pp. 235-239. 
of age, if this is desirable for legal protection of their interests ( $§ 58 \mathrm{a}$ StPO). Such a recording may only be used for the purposes of prosecution if it is necessary for detection of the truth (subsidiarity clause). Moreover, the data of the examined person are removed from the case file ${ }^{21}$. It is worth noting that if such a recording is ordered by an investigating judge (Ermittlungsrichter), the witness can appeal against such a decision ( $\$ 309$ (2) StPO). Moreover, the witness may contest the inclusion of a copy of the recording in the case file; in such case, it is replaced by a written report (§ $58 \mathrm{a}(3) \mathrm{StPO})^{22}$.

On the other hand, $\S 247 \mathrm{a}$ StPO stipulates that in case of a serious threat to the witness's health or safety, the witness may be examined remotely using audiovisual equipment, unless this restricts the possibility of reaching of substantive truth. The decision on this form of examination is non-actionable. The image and sound from the examination are transferred to the courtroom. This is also true for testimonies of the witness in case of fear that they would not appear at the hearing and their testimony is crucial for detection of truth ${ }^{23}$. As pointed out in the German literature, although the possibility of replacement of direct witness examination at a hearing pursuant to $\S 255 \mathrm{StPO}$ with replay of a recording made pursuant to $\S 58 \mathrm{a}$ StPO may violate the defendant's right to defence, real-time examination by videoconference, as stipulated under $\S 247 \mathrm{a}$ StPO, deserves approval since it enables protection of a victim, while simultaneously preserving the defendant's right to confrontation of witnesses pursuant to Article 6 (3) (d) ECHR, since the defendant is provided with a right to participate in such a hearing ${ }^{24}$.

The Code also provides for a possibility to remove the defendant from the courtroom for the time of examination of victim below 18 years of age if the defendant's presence would compromise the witness's freedom of expression, or if it would give rise to serious hazard to the health of an adult witness ${ }^{25}$. In the German doctrine, it is considered appropriate to provide specific legal assistance to victims of crimes so they could benefit from such protective measures as examination by videoconference, but not for the purpose of supporting thereof in the capacity of an accessory prosecutor ${ }^{26}$.

Article 185a $\S 1$ of the Polish CCP states, that in cases concerning offences committed with the use of violence of illegal threat or defined in Chapters XXIII ("Offences against freedom"), XXV ("Offences against sexual freedom and decency") and XXVI ("Offences against family and guardianship") of the Criminal
${ }^{21}$ Ibidem.
${ }^{22}$ M. Huber, [in:] Strafprozessordnung..., pp. 144-148.
${ }^{23}$ L. Meyer-Gossner, B. Schmitt, op. cit., pp. 1117-1124.
${ }^{24}$ B. Schünemann, op. cit., pp. 390-392. See also F.Ch. Schroeder, Strafprozessrecht, München 1997, p. 224.

25 J. Berg, [in:] Strafprozessordnung..., pp. 962-969.

${ }^{26}$ B. Schünemann, op. cit., p. 395. 
Code, an injured person who is below the age of 15 at the time of the examination testifies as a witness only once, unless important circumstances come to light, the clarification of which requires a second examination, or unless the accused who was not assisted by a defence counsel during the first testimony so demands. The examination is conducted by the court with the attendance of an expert psychologist. The public prosecutor, the defence counsel and the attorney of the injured party may participate in the examination. Victim's legal representative or a person, under whose permanent care the injured person remains or an adult person indicated by the injured person referred to in $\S 1$ may attend the examination, if this does not limit the freedom of expression of the person giving testimony. If the accused notified of this procedure does not have a defence counsel of his own choice, the court appoints for him a defence counsel ex officio. In cases concerning offences referred to in $\S 1$, a minor injured party who at the time of the examination has attained 15 years of age, is examined in the conditions specified in $\S 13$, if there is a justified concern that the examination carried out in different conditions might have a negative impact on his mental state.

To sum up, it can be concluded that the current wording of the Article 185a CCP justifies the thesis (which was put forward even before the amendment of this regulation) that it constitutes a reasonable compromise between the protection of the freedom of expression of a minor witness and the requirements of effective defence of the accused, without "prejudice to the principle of the presumption of innocence of the accused" (see recital 12 of the preamble to the Directive 2012/29/EU) ${ }^{27}$.

On the other hand, Article 185c CCP stipulates, that in cases concerning offences referred to in Articles 197-199 of the Criminal Code (rape and sexual assault), report of the offence submitted by the injured person should be limited to the most important facts and evidence. The examination of the injured person in the capacity of a witness is conducted by the court in a hearing, which may be attended by the public prosecutor, the defence counsel and the attorney of the injured person. In cases concerning such offences, an injured person over 15 years of age at the moment of examination is only examined as a witness if their testimony may be of crucial importance to resolution of the case, and only once, unless significant circumstances the explanation of which requires repeated examination come to light (Article 185c § 1a CCP). Contrary to the German StPO, the defendant does not participate in any of those examinations.

${ }^{27}$ Cf. C. Kulesza, P. Starzyński, [in:] Dyrektywa Parlamentu Europejskiego i Rady ustanawiajaca normy minimalne $w$ zakresie praw, wsparcia i ochrony ofiar przestępstw. Komentarz, eds. E. Bieńkowska, L. Mazowiecka, Warszawa 2014, p. 137; C. Kulesza, [in:] Kodeks postępowania karnego. Komentarz, ed. K. Dudka, Warszawa 2018, pp. 396-401 and the Supreme Court case-law cited thereof. 
Examinations referred to in Articles 185a-185c CCP are carried out in the premises adequately adapted for this purpose (in the seat of the court or out of it), the vision and sound of the hearings are recorded and played at the main trial.

In exceptional circumstances, when there is a reason to fear that the presence of the accused might inhibit the testimonies of a witness, the presiding judge may order that the accused should leave the courtroom for the duration of a given person's examination. In the circumstances indicated above the presiding judge may also carry out the examination with the use of technical devices allowing this procedure to take place remotely, with simultaneous transmission of sound and vision (Article $390 \S \S 2$ and $3 \mathrm{CCP}$ ).

THE CONFLICT BETWEEN THE PROCEDURAL RIGHTS OF A VICTIM AND THE DEFENDANT'S RIGHTS IN THE DECISION-MAKING SPHERE OF THE PROCEEDINGS

\section{The victim's impact on the initiation and conduct of criminal proceedings}

According to Article 11 of the Directive 2012/29/EU the right to a review of a decision not to prosecute should be understood as referring to decisions taken by prosecutors and investigative judges or law enforcement authorities such as police officers, but not to the decisions taken by courts. A decision ending criminal proceedings should include situations where a prosecutor decides to withdraw charges or discontinue proceedings (recital 44). A decision of the prosecutor resulting in an out-of-court settlement and thus ending criminal proceedings, excludes victims from the right to a review of a decision of the prosecutor not to prosecute, only if the settlement imposes a warning or an obligation (recital 45).

German preparatory proceedings is ruled by the obligation on the part of the public prosecution office to launch investigation proceedings and investigate the factual situation, provided that sufficient actual indications of a crime exist. This principle, which is set forth in $\S 152$ (2) and $\S 160$ (1) StPO, and obligates the public prosecution office to take action, is referred to as the Legalitätsprinzip, or the "principle of legality" 28 . In fact, the evolution of criminal policy associated with the increase in petty and moderate crime (Bagatelldelikte) is gradually replacing the principle of legalism with the principle of opportunism (Opportunitätsprinzip) in process practice ${ }^{29}$.

${ }^{28}$ See S. Beukelmann, [in:] Strafprozessordnung..., pp. 632-633; C. Roxin, B. Schünemann, Strafverfahrensrecht, München 2009, pp. 69-78.

${ }^{29}$ R. Juy-Birman, The German system, [in:] European Criminal Procedures, eds. M. Delmas-Marty, J.R. Spencer, Cambridge 2008, pp. 308-309. 
After completing its investigations, the public prosecution office considers whether public charges are to be preferred. If it does not prefer public charge, it must inform the complainant of its decision and indicate the reasons therefore. Moreover, the public prosecution office must inform the injured person of the criminal offence of the possibility of contesting this decision ( $\$ 171$ StPO). The injured party then has the opportunity to lodge a complaint within two weeks with the Office of the Public Prosecutor General against the decision of the public prosecution office (§ 172 (1) StPO). If this complaint is dismissed by the Office of the Public Prosecutor General, the injured person may move within one month to the Higher Regional Court for a decision on whether to reopen the investigation proceedings ( $\$ 172(2-4)$ StPO).

In the German legal system actions such as the private accusation (Privatklage) and the accessory accusation (Nebenklage) open up a wide range (at least theoretically) for the initiative by the injured person. From the point of view of injured person protection, it is important for injured person to be able to join the public prosecution as an accessory prosecutor (Nebenkläger). Joining the public prosecution as a private accessory prosecutor gives the injured persons named in $\S 395$ StPO comprehensive powers to participate in the entire proceedings starting with the preferment of public charges. Private accessory prosecutors have the possibility of contributing actively to the proceedings and influencing them by means of statements, questions, motions and appellate remedies. In the case of private accusation a "private initiative" is (at least in theory) more effective as the action taken by individual then appears as an autonomous means of seising the courts. It is worth to underline here the risks involved: the public prosecutor can take over the case from the victim seising of the court and the accused may counter-claim for damages $^{30}$. The private accusation is, however, extremely limited in its sphere of application. In neither case does the private action exclude the power of the public prosecutor to drop the case. In Germany, the victim has also the possibility provided by $\S 403 \mathrm{ff}$. StPO of asserting a claim for damages against the wrongdoer as early as the criminal proceedings stage by means of a so-called "adhesion procedure" (Adhäsionsverfahren) ${ }^{31}$.

It is worth noting that an injured person not acting in the capacity of a prosecutor or a civil plaintiff is entitled to extensive rights to information on the status of the case and the decisions taken in its course, as well as on the injured person's own rights ( $§ 496 \mathrm{~d}$ StPO): the right to inspect files ( $§ 496 \mathrm{e} \mathrm{StPO})$, the right to legal aid

${ }^{30} \mathrm{Cf}$. M. Peter, Measures to protect victims in German criminal proceedings. A summary with special focus on the key points of the Second Victims' Rights Reform Act, www.unafei.or.jp/publications/pdf/RS_No81/No81_13VE_Peter.pdf [access: 20.05.2020], pp. 132-135.

${ }^{31}$ C. Roxin, B. Schünemann, op. cit., pp. 477-480. 
of an assistant ( $\$ 496 \mathrm{f}$ StPO), and the right to procedural care exercised by a social psychologist (§ 496g StPO) $)^{32}$.

The German literature points out that the rights of active participation of an injured person as an accessory prosecutor, private prosecutor or civil plaintiff in the German procedure may upset the balance of powers between the prosecution and the defence. Under such circumstances, the defendant may face an entire "phalanx" of prosecutors ${ }^{33}$. However, the rights of an injured person as a party to the procedure are seldom exercised in the procedural practice ${ }^{34}$.

The Polish justice system like the German system is based on the principle of legality and upholds the model of procedural rights. Therefore, the injured person is a party to the preparatory proceedings and during the trial he may exercise the rights of auxiliary prosecutor or private prosecutor. In the case of offences prosecuted $e x$ officio, the injured party may act as a party to the proceedings in the capacity of the auxiliary prosecutor alongside the public prosecutor (accessory prosecutor) or in his place (subsidiary prosecutor).

The injured party's involvement in the public prosecution as an accessory prosecutor in the Polish Code of Criminal Procedure is similar to the German process and requires only a statement at the latest before the opening of the evidence proceedings at the trial. A new approach to Article $14 \S 2 \mathrm{CCP}$ required to safeguard the interests of accessory prosecutor, which should not be deprived of their rights due to the fact that the public prosecutor withdraws the indictment. Provided, therefore, a design change in Article $54 \S 2 \mathrm{CCP}$, according to which the withdrawal of the indictment by the public prosecutor does not deprive the accessory prosecutor of his rights. The injured party, who previously has not used the rights of accessory prosecutor may, within fourteen days of being informed of the withdrawal of the

${ }^{32}$ L. Meyer-Gossner, B. Schmitt, op. cit., pp. 1611-1621.

${ }_{33}$ B. Schünemann, op. cit., p. 395. See also F.Ch. Schroeder, op. cit., p. 224.

34 In case of institution of "enforced complaint" (Klageerzwingungsverfahren - § 172 StPO), infrequent exercise thereof (only 2,423 complaints against a decision not to prosecute were brought to the Court of Higher Instance in 2018) is caused by the fact that the injured party must lodge a security for the costs of the proceeding before submitting the complaint, and reimburse these costs to the State Treasury and the defendant if the case is lost. In Germany, 320 cases $(0.005 \%$ of all cases) were pending under the private-complaint mode before courts of lower instance (Amtsgericht) in 2018; the courts examined 5,573 adhesion claims ( $0.08 \%$ of the total number of cases), of which $1,823(32.7 \%)$ ended in a court settlement. Before these courts, accessory prosecutors/their attorneys would appear at 7,393 hearings ( $1.5 \%$ of all hearings), whereas defenders would appear at 220,670 hearings ( $45.4 \%$ of all hearings). Regional courts (Landesgericht) examined 596 civil actions $(4.5 \%$ of all cases) in 2018, of which 126 (21.1\%) ended in a court settlement. Before these courts in 2018, accessory prosecutors/their attorneys would appear at 2,152 hearings ( $21.5 \%$ of all hearings), whereas defenders would appear at 9,272 hearings ( $92.6 \%$ of all hearings). Source: own elaboration based on Statistisches Bundesamt, Berlin 2019, www.destatis.de [access: 20.01.2020], p. 19, 23, 35, 61, 73. 
indictment by the public prosecutor, declare that he will join the proceedings in the capacity of the subsidiary prosecutor.

If victims of crime wish to bring their own indictment to the court as subsidiary prosecutors, they need to undergo a complex procedure. First, they have to bring an effective appeal to the court against the public prosecutor's decision on refusal to initiate or on discontinuation of the proceeding. If the court reverses the contested decision not to prosecute, and the public prosecutor issues an identical decision again, the victim may appeal against it to a superior public prosecutor. If the superior public prosecutor fails to recognize the complaint, the injured person, with the help of their attorney, may bring his or her own indictment to the court within one month since being notified of this fact. A successful prosecutor's accession to the circumstances stated above rules will require assistance from an attorney. An attorney may be appointed by the injured person (agent of choice) or appointed by the president of the court.

The injured party is entitled to participate in the trial if he or she appears and remains in the courtroom, even if he or she will testify as a witness. In this event, the court examines this person first.

However, a study conducted in 2012 by the Polish Institute of Justice in Warsaw showed a low level of activity of a subsidiary prosecutor. Furthermore, the low effectiveness of the subsidiary complaints lodged is evidenced by the fact that in the period of time studied, the percentage of convicting judgements and judgements conditionally discontinuing the legal proceedings did not exceed $18 \%$. The records suggest that the subsidiary prosecutor is merely an addition to the proceedings, generally an unwelcome one, as they necessitate additional court activities, e.g. summons to the case and sometimes its adjournment ${ }^{35}$. Concerning the activity of a private prosecutor, there were 1,358 valid convictions by private prosecution in Poland in 2017 , accounting for approx. $0.5 \%$ of all convictions ${ }^{36}$.

${ }^{35}$ K. Dudka, G. Artymiak, Sytuacja pokrzywdzonego w procesie karnym ze szczególnym uwzględnieniem oskarżyciela posiłkowego i powoda cywilnego, Warszawa 2012, pp. 66-67.

36 Skazania prawomocne - z oskarżenia prywatnego - dorośli - w latach 2013-2017, Warszawa 2018, https://isws.ms.gov.pl/pl/baza-statystyczna/opracowania-wieloletnie [access: 20.02.2020], p. 1. As opposed to infrequent application and low efficiency of the institution of complaint enforcement in Germany, Polish courts examined 55,275 complaints against refusal to initiate or discontinuation of a preparatory proceeding in 2018, recognizing 14,232 and dismissing 41,043 complaints. As for the protective function of non-isolation preventive measures in 2018, prosecutors applied the injunction to leave the dwelling occupied together with the injured person in 4,121 cases. The role of a (non-prosecutor) injured party in challenging the procedural agreements is significant, since in 2018, the courts convicted on the public prosecutor's request, without a trial (Article 335 CCP), in 76,276 cases, and recognized the defendant's motion for voluntary submission to penalty (Article $387 \mathrm{CCP})$ in 14,800 cases, comprising, together with penalty orders $(58,860)$, a total of $53.9 \%$ of all convictions. Source: own elaboration based on Sprawozdanie z działalności powszechnych jed- 
The most recent file research also shows low activity of auxiliary prosecutors in appeal proceedings (including evidence) and low efficiency of their appeals against judgements of district courts ${ }^{37}$.

In the Polish literature, noting that the injured party acts as a party and as a source of evidence in the criminal proceedings, it is emphasized:

While in the former case the injured party retains freedom of action limited by the general rules of criminal procedure, in the second case he or she is subject to the same evidentiary rigour as a person who have no interest at all in the subject matter and outcome of the trial ${ }^{38}$.

Therefore, the literature indicates the problem whether statements of knowledge made by an auxiliary prosecutor are subject to the same evidentiary rigour as his testimony as a witness, finally pointing out that the idea of guaranteeing the protection of the rights of the injured party is closer to the idea of not treating the free expressions of the auxiliary prosecutor in the same way as the testimony, despite the difficulties that may arise in distinguishing between the two types of deposition of the injured party ${ }^{39}$. These observations on the reliability of an injured party's deposition must be taken into account when assessing his rights in the cognitive and decision-making sphere of the criminal process.

\section{The injured party and the procedural agreements}

A conflict with lasting consequences which might directly affect the conditions of conviction of a defendant and of holding them liable may be caused by granting the injured person with a right to contest procedural agreements, i.e. conviction without a trial and voluntary submission to the penalty. However, in such case, it should be deemed proper to enhance the rights of the injured person so they would be able to enforce conviction of the defendant under conditions "also taking account of the legally protected interests of the injured person", and in particular, to make their consent for conviction dependent on the redress of the damage by the defendant or on compensation for the suffered harm. This thesis is justified by the fact that the Polish CCP considers the principle of taking into account the legally protected interests of the injured party with due respect for his or her dignity as one of the aims of the criminal proceedings (Article $2(3) \mathrm{CCP})^{40}$.

nostek organizacyjnych prokuratury w sprawach karnych za rok 2018, https://pk.gov.pl/wp-content/ uploads/2019/04/PG_P1K.pdf [access: 25.01.2020], pp. 3-4, 6 .

${ }^{37}$ Cf. D. Kużelewski, Protection of the aggrieved party's rights in the appeal proceedings, [in:] Fairness of the New Model of Polish Criminal Appeal Proceedings in the Context of Delivered Research, ed. C. Kulesza, Bialystok 2019, pp. 215-236.

${ }^{38}$ Ibidem, pp. 125-126.

${ }^{39}$ Ibidem, pp. 126-127.

${ }^{40}$ See e.g. judgement of the Supreme Court of 12 February 2019, II KK 291/18, Legalis. 
An auxiliary prosecutor may also appeal against the judgement but it can not be based on a mistake in the findings of fact adopted as the basis of the judgement or on the gross disproportionality of the penalty, penal and compensatory measure (Article 447 \& 5 CCP).

In Germany, procedural agreements are formalised because a judgement accepting an agreement can only be made after the main trial. An auxiliary prosecutor may take a stand on the agreement between the prosecution and the defence, but may not oppose it ( $\$ 257 \mathrm{c} \mathrm{II} \mathrm{StPO).} \mathrm{However,} \mathrm{in} \mathrm{cases} \mathrm{where} \mathrm{he} \mathrm{or} \mathrm{she} \mathrm{acts} \mathrm{as} \mathrm{an}$ auxiliary prosecutor, he or she has the full right to appeal (Berufung) or a review (Revision) or even an application for resumption of the proceedings ended with a final judgement ${ }^{41}$.

\section{The protective function of preventive measures and the defendant's rights}

Directive 2012/29/EU does not mention preventive measures, and provisional custody in particular, among the measures of protection of victims of crimes. It only stipulates, that Member States shall ensure that victims are offered the opportunity to be notified, without unnecessary delay, when the person remanded in custody, prosecuted or sentenced for criminal offences concerning them is released from or has escaped detention. Member States shall also ensure that victims are informed of any relevant measures issued for their protection in case of release or escape of the offender (Article 7 para. 5).

Therefore, it should be noted that the German StPO provides separate basis of application of protective custody (Sicherungshaft) if there is a high degree of suspicion that the defendant has committed a serious offence, in particular, against sexual freedom or of harassment of another person, putting that person at risk of loss of life or health, and the existing circumstances substantiate a concern that the defendant would commit a new, equally grave offence before the conviction $(\S 112 \mathrm{a}$ StPO). Comments point out that such application of preventive custody does not violate the German constitution and is provided for in Article 5 I c ECHR. In view of the above, it is not contrary to the principle of presumption of innocence as set forth in Article 5 II ECHR. Provisional custody may be repealed the circumstances make it evident that the defendant will comply with the imposed obligations (e.g. obligation of therapy, injunction to stay away from the injured persons, or prohibition of change of residence) which will enable achievement of the purpose of the arrest, i.e. prevent the risk of repeated offence ${ }^{42}$. According to $\S 406 \mathrm{~h} \mathrm{StPO}$, the injured persons were to be made aware in particular of the possibility of being notified, upon application, not only of the outcome of proceedings, but also whether

${ }^{41}$ Cf. L. Meyer-Gossner, B. Schmitt, op. cit., pp. 1171-1185.

${ }^{42}$ Ibidem, pp. 563-566, 587. 
custodial measures against the defendant or convicted person have been ordered or terminated, and whether relaxation of the conditions of detention or leave from detention has been granted for the first time; this applies if the victim can show a legitimate interest in receiving this information and if there is no overriding interest on the part of the defendant or convicted person which constitutes an obstacle to providing such information ${ }^{43}$. Apart from preventive custody, the German procedure enables application of non-isolation preventive measures, such as placing at a psychiatric or drug rehabilitation institution, prohibition of pursuit of a specific profession, or withholding of the driving license.

The Polish law provides for a separate basis of application of preventive measures (including preventive custody) on the basis of fear of repeated offence. It may be applied if there are substantiated concerns that the defendant charged with perpetration of a crime or an intentional misdemeanour will commit an offence against life, health or common security (Article 258 (3) CCP). It should be noted that the right to defence is excessively restricted by the regulation stipulating that witness summaries are not made available to the defence during consultation with the file of the custody case if the public prosecutor decides that the life, health or freedom of the witness or their closest relatives is endangered. Nevertheless, evidence from such testimony may serve as a basis for the court's decision concerning the custody. The Polish literature indicates that this regulation, by limiting the defendant's right to defence, does not contain limitations in the form of "exceptional case" and "non-violation of the right to a fair trial" and "serious threat" to a specific legal good, which makes it incompatible not only with Strasbourg standards, but also with Directive 2012/13/EU of the European Parliament and of the Council of 22 May 2012 on the right to information in criminal proceedings ${ }^{44}$. There is no similar regulation in the German StPO and the court must provide all the evidence on which it bases its order of the temporary custody, unless there is a threat to state security (§ 114 III StPO $)^{45}$.

Among non-isolation preventive measures of particular importance to protection of injured persons, especially victims of "domestic violence", the following should be mentioned:

- inclusion of such supervisory obligations as the prohibition to contact the injured person or other persons, the prohibition to approach specific persons closer than a prescribed distance and the ban on entering specific places,

${ }^{43}$ B. Weiner, [in:] Strafprozessordnung..., pp. 1763-1766.

44 J. Skorupka, [in:] Kodeks postępowania karnego. Komentarz, ed. J. Skorupka, Warszawa 2020, pp. 320, 568-569. See also M. Prusek, Utajnienie zeznań świadka w procesie karnym a realizacja konstytucyjnej zasady proporcjonalności, „Palestra” 2017, no. 7-8, pp. 29-36.

${ }^{45}$ L. Meyer-Gossner, B. Schmitt, op. cit., p. 569. 
- conditional police supervision provided that the defendant leaves the dwelling jointly occupied with the injured person within the prescribed time and specifies the place of their residence,

- order to temporarily leave the premises by a person charged with the offence of domestic violence under Article 275a CCP, if there are substantiated concerns that the defendant would repeat such offence, especially if they have already threatened to commit it.

Although application of preventive measures intended to protect the injured person may rise a conflict with the defendant's rights, this conflict is temporary, since it may last no longer than the valid completion of the proceeding, when the principle of presumption of innocence ceases. On the other hand, some file studies have noted the ineffectiveness of the legal protection of a child victim of cruelty (Article 207 of the Criminal Code) in criminal proceedings, in particular the failure to apply the preventive measure of ordering the perpetrator to leave the place of cohabitation with the victim, provided for in Article $275 \mathrm{CCP}^{46}$.

\section{RIGHT TO LEGAL AID}

The main regulation concerning victim's access to legal aid is Article 13 of the Directive 2012/29/EU stating that Member States shall ensure that victims have access to legal aid, where they have the status of parties to criminal proceedings. The right to legal advice is a key issue in procedural rights for victims. A victim who is assisted by an effective lawyer is in a far better position with regards to the enforcement of all his other rights, partly because he is better informed of those rights and partly because a lawyer is able to assist him in ensuring that his rights are respected. In Germany, victims entitled to appear as accessory prosecutors have the right to benefit from legal aid provided by an assistant even before the hearing, regardless of whether or not they take part in the proceeding ( $\$ 397 \mathrm{a}$ StPO). In case of sexual offences, homicide or aggravated assault, they may obtain ex officio legal aid at the cost of the State Treasury, regardless of their financial standing ( $\$ 397 \mathrm{a}$ (1) StPO). Legal counsels of an accessory prosecutor may exercise all rights on

${ }^{46}$ O.Trocha, Udziat dzieci w postępowaniu karnym - wyniki badań, obserwacje, rekomendacje, „Dziecko krzywdzone. Teoria, badania, praktyka” 2013, vol. 12(4), p. 62. See also K. Dudka, Praktyka stosowania nieizolacyjnych środków zapobiegawczych w polskim procesie karnym, Warszawa 2015; C. Kulesza, Fair trial for a victim of crime? - European standards and Polish experience, Paper presented at the $16^{\text {th }}$ International Symposium of the World Society of Victimology "Victims and Victimization: Moving Towards an International Victimology", Hong Kong, 10-14 June 2018, www. cityu.edu.hk/ss_wsv2018/about/files/Conc/Cezary\%20Kulesza\%20-\%20Fair\%20trial\%20for\%20 victims.pdf [access: 20.02.2020]. 
their behalf as a party to a procedure. They also have the right to inspect court and prosecution files without a necessity to demonstrate the legal interest.

Victims unable to serve as accessory prosecutors, appearing in the capacity of a witness, also have the right to legal representation by an attorney (Zeugenbeistand/ Verletztenbeistand, $\S \S 68 \mathrm{~b}$ and $406 \mathrm{f} \mathrm{StPO).} \mathrm{The} \mathrm{role} \mathrm{of} \mathrm{a} \mathrm{legal} \mathrm{representative} \mathrm{con-}$ sists in accompanying the witness/injured party during examination at the preparatory proceeding and at the hearing, as well as during physical tests, inspection of the case file, legal support and advice. A legal counsel for the actions of examination may also be appointed ex officio. Case files may be provided to the counsel if he shows a legal interest (e.g. bringing a civil action), and reading those files does not endanger the purpose of the proceedings or extend it.

In the Polish criminal process, neither the injured party nor his or her attorney have to prove such interest when examining the case file.

The Polish CCP provides for, that in contrast to the defense, appointment of an attorney by the victim is always optional. An attorney may be appointed by the injured party (agent of choice) or appointed by the president of the court (agent ex officio). As pointed out in the case law, in criminal proceedings for the issue of the establishment of legal aid will prevail only the facts of the financial situation of the parties ("law of poor"). Also under the Polish law, all injured persons must be instructed before the first examination about their rights, they may use the aid of representatives (including ex officio ones) or from company of a trusted person in the preparatory proceeding.

\section{THE IMPACT OF THE VICTIM'S BEHAVIOUR ON THE DEFENDANT'S CRIMINAL LIABILITY UNDER THE GERMAN AND POLISH LAW}

The traditional institution of the criminal law, taking account of the impact of the victim's behaviour on the defendant's criminal liability, is justification excluding the unlawfulness of the act: self-defence. The German Criminal Code (StGB) stipulates that a defendant who averts an attack by committing an act in self-defence, i.e. in defence necessary to avert a present unlawful attack on oneself or another, does not act unlawfully (Section $32 \mathrm{StGB}$ ). On the other hand, if the limits of self-defence were exceeded due to confusion, fear or fright, the offender incurs no penalty (Section 33 StGB).

Article 25 of the Polish Criminal Code provides that: "§ 1 . Anyone who, out of necessary self-defence, repels a direct illegal attack on any legally protected interest is not deemed to have committed an offence. $\S 2$. If the self-defence exceeds what is necessary, in particular when the offender uses a means of defence disproportionate to the danger of the attack, the court may apply an extraordinary mitigation of the penalty, or even issue an absolute decree. $\S 3$. The court will issue an absolute 
discharge if the limits of necessary self-defence were exceeded as a result of fear or emotional distress, justified by the circumstances of the attack".

Thus, in both codes, a ground excluding the unlawfulness of the defendant's act may be necessary defence against an unlawful, immediate attack by the victim. If the defence of a defendant affected by fear, confusion or rage is disproportionate to the attack, the offender incurs no penalty under the German law, and the court may renounce from inflicting a punishment or mitigate it extraordinarily under the Polish law. Thus, while assessing whether or not the defendant has committed an offence, courts must consider the impact of the victim's most serious provocation, namely, the attack. It should be added that both Polish Criminal Code and German StGB do not require the defendant to defend themselves against the attack and allow self-defence against an attack on another person. Moreover, the Polish Criminal Code introduces no limitations concerning the defended interest, since the attack may be directed against any interest. Such a broad definition of self-defence is non-existent in Germany and rare in Europe.

The behaviour of a crime victim should also be taken into consideration by courts when punishing a defendant. Under the German code, such a directive results from the judicial case-law, whereas in the Polish law, it is indicated outright in Article 53 (2) of the Criminal Code. Under both criminal justice systems, the court takes account of the results of mediation between the defendant and the offender and the defendant's efforts to make restitution for the harm caused by the offence (Section 46a StGB and Article 53 (3) of the Polish Criminal Code) ${ }^{47}$. However, as pointed out in the Polish doctrine and case-law, the victim's contribution, connected with attribution of joint responsibility for a part of the negative consequences of the act, may result in attribution of a lower quantum of seriousness of the same act, and consequently lower degree of guilt, to the offender. The reduction of the offender's guilt may only be affected by such contribution of the injured person which was culpable ${ }^{48}$.

Referring to J.J. Gobbert's view on the impact of the victim's contribution on the defendant's liability for violent crimes, it should be pointed out, due to the limited framework of this article, that both German and Polish law include it in the constituent elements of such crimes as e.g. murder of passion (Article $148 \S 4$ of the Polish Criminal Code and $\S 213$ StGB) and rape (Article 197 of the Polish Criminal Code and $\S 177 \mathrm{StGB})^{49}$.

${ }^{47}$ Cf. C. Kulesza, D. Kużelewski, Victim-offender mediation as an alternative to the criminal justice system in Poland, "Temida" 2018, vol. 21(1), DOI: https://doi.org/10.2298/TEM1801003K, pp. 10-18.

${ }^{48}$ Cf. W. Wróbel, [in:] Kodeks karny. Część ogólna. Komentarz, ed. A. Zoll, vol. 1, Kraków 2007 and the Supreme Court case-law cited therein.

49 See comments to these regulations respectively - in Polish literature: M. Budyn-Kulik, Komentarz do art. 148, [in:] Kodeks karny. Komentarz aktualizowany, ed. M. Mozgawa, LEX/el. 2020; 
Pobrane z czasopisma Studia Iuridica Lublinensia http://studiaiuridica.umes.pl

Data: 26/04/2023 08:06:13

156

Cezary Kulesza

\section{THE CONFLICT BETWEEN THE RIGHTS OF VICTIMS OF CRIMES AND THE RIGHTS OF A DEFENDANT IN THE CASE-LAW OF EUROPEAN COURTS}

\section{The case-law of the CJEU}

The case-law of the CJEU concerning the Framework Decision 2001/220 on the standing of victims in criminal proceedings interpreted, above all, regulations concerning the protection rights of victims of crimes, in the context of their conflict with the defendant's right to defence. The CJEU judgement of 16 June 2005 in the case of Maria Pupino (C-105/03b) should be considered a breakthrough in the area of protection of the rights of minor witnesses, as it states that a national court must be able to authorize young children who claim to have been victims of maltreatment to give their testimony in a manner ensuring them an appropriate level of protection, e.g. outside the public trial and before it is held. From the CJEU's case-law referencing the rights of victims of crimes, as specified in the Framework Decision 2001/220, the following theses can be derived in particular:

- the concept of a victim relates to natural persons and does not include legal entities $^{50}$,

- Member States need not grant victims with accusatory rights in legal proceedings ${ }^{51}$,

- Member States are not obliged to enable mediation as a form of resolution of the offender-victim conflict in case of all offences and may apply victim protection measures regardless of the victims' will ${ }^{52}$.

When assessing the protection rights of adult victims, one of the most recent CJEU rulings of 29 July 2019 should be taken into account, which, with regard to adult victims of fraudulent crimes, states that "Articles 16 and 18 of Directive 2012/29/EU [...] must be interpreted as not precluding national legislation under which, where the victim of a criminal offence has already been examined by a panel of judges of a first-instance court and the composition of that panel is subsequently

Zmodyfikowane typy przestępstw w teorii i praktyce sądowej, eds. J. Giezek, J. Brzezińska, Warszawa 2017; in German literature: K. Kühl, M. Heger, Strafgesetzbuch. Kommentar, München 2016, pp. 865-972, 1034-1035; T. Hörnle, The New German Law on Sexual Assault and Sexual Harassment, "German Law Review" 2017, vol. 18(6), DOI: https://doi.org/10.1017/S2071832200022355, pp. 1314-1323.

${ }^{50}$ Case C-467/05, Giovanni Dell'Orto (28 June 2007), ECR I-05557, para. 52-54; Case C-205/09, E. Eredics, M.V. Sápi (21 October 2010), ECR I-10231, para. 26-27.

${ }^{51}$ Case C-404/07, G. Katz v. I.R. Sós (10 July 2008), ZOTSiS 2008/10/I-7607, para. 44-47; Case C-507/10, X(21 December 2011), ZOTSiS, 2011/12C/I-14241-14284, para. 43.

${ }^{52}$ Case C-483/09, Gueye and Salmerón Sánchez (15 September 2011), ECR-I-10231, para. $73-74$ 
changed, that victim must, in principle, be examined again by the panel in its new composition, where one of the parties to the proceedings does not consent to that panel basing its decision on the written record of the evidence the victim gave at the first examination" 53 .

Of course, it should be taken into account that in the Polish process, if the composition of judges in the court is changed after the hearing, is interrupted or postponed pursuant to Article $402 \S 2$ and Article $404 \S 2$ CCP respectively, the hearing must be conducted at a new date from the beginning. Such a solution is not provided for in $\S 229$ of the German StPO.

\section{The case-law of the ECtHR}

The principal purpose of the European Convention on Human Rights is the protection of the rights of individuals from infringement by states. However, in the context of the consideration of this article, it should be noted that the conflict between the protection rights of victims and the rights of the accused may arise. It is also possible that a conflict may occur in the area of adjudication, between the defendant's right to a fair trial under Article 6 (1) ECHR and the rights of victims of crimes or their families to make opinions before the court concerning the results of the offence as well as the defendant's criminal responsibility and compensation for the damage and harm resulting from the offence ${ }^{54}$. However, analyses of the ECtHR's case-law concerning gross violations of human rights allow the conclusion that the offenders' obligations to compensate for damages, as imposed by the retributive case-law of the ECtHR, are of significant value to satisfaction of the victims' needs in the area of restitution, simultaneously acting as guarantees of prevention of their future victimization ${ }^{55}$.

Finally, it should be noted that, in the opinion of the ECtHR, private-complaint proceeding is connected neither with the "dispute" concerning the rights and obligations of a complainant of civil nature, nor with indictment in a criminal case against them within the meaning of Article $6 \mathrm{ECHR}^{56}$.

${ }^{53}$ Case C-38/18, Massim Gambin and Shpetim Hyka (29 July 2019), https://eur-lex.europa.eu/ legal-content/EN/TXT/HTML/?uri=CELEX:62018CJ0038\&from=EN [access: 20.04.2020], para. 60.

${ }^{54}$ B. Emmerson, A. Ashworth, A. Macdonald, L.-T. Choo, M. Summers, Human Rights and Criminal Justice, London 2012, pp. 828-832 and the ECtHR's case-law cited therein.

55 A. Bala, Victims and Retributive Responses at the European Court of Human Rights: Scrutinizing the Coercive Dimension of Reparations, "iCourts Working Paper Series" 2019, no. 155, DOI: https://doi.org/10.2139/ssrn.3337689, pp. 1-22 and the ECtHR's case-law cited therein.

56 Wilczyński v. Poland (complaint no. 35110/10), 12 September 2017, para. 30-31. 
Three kinds of protective laws which may comprise substantiated grounds for restriction of the defendant's rights under Article 6 ECHR may be distinguished in the ECtHR's case-law ${ }^{57}$ :

1) protection of the identity of a witness (victim) in case of concerns that the defendant would take their revenge,

2) protection of the rights of victims-witnesses against violations during examination at the hearing,

3 ) restriction of the access to the medical documentation of victims-witnesses. In particular, one may point out the conflict between the principle of adversary proceeding and equality at arms as the guarantees of the defendant's right to defence (Article 6 (3) (d) ECHR) and the closest relatives' right to refusal to testify ${ }^{58}$ and the protective rights of minor victims of sexual offences ${ }^{59}$.

\section{CONCLUSION}

Comparing the rights of injured persons in the capacity of procedural parties in Poland and Germany, it should be noted that the institution of an auxiliary prosecutor in Poland has a broader extent, since the injured party may appear in this capacity in all offences prosecuted by public indictment, not only in addition to a public prosecutor (as an accessory prosecutor) but also instead of them (as an independent subsidiary prosecutor). Moreover, pursuant to the Polish CCP, even a non-prosecutor injured party may raise an objection concerning procedural agreements and appeal against a judgement conditionally discontinuing the proceeding during a session. A court, when adjudicating on conviction under consensual modes and conditionally discontinuing the proceeding, takes account of the civil-law interests of the injured party concerning redress of the damage or compensation for the harm caused by the offence, and also takes an agreement between the defendant and the injured party in this regard (e.g. concluded during mediation) into consideration. However, in neither of the countries under analysis is the injured person entitled to appeal against a decision by a public prosecutor or a court in the area of application

${ }^{57}$ B. Emmerson, A. Ashworth, A. Macdonald, L.-T. Choo, M. Summers, op. cit., pp. 823-828.

58 See e.g. N.K. v. Germany (complaint no. 59549/12), 26 July 2018, para. 59-62.

59 In the case Przydziat v. Poland (complaint no. 15487/08, 24 May 2016), the ECtHR admitted that failure to notify the defender of examination of the injured minor by the court in the preparatory proceeding and decision not to examine her at the hearing due to her mental condition did not violate the defendant's right to fair trial, since there was other direct evidence in that case (para. 53-55). See also A. Lach, Postepowanie dowodowe w sprawach karnych w świetle orzecznictwa strasburskiego, Warszawa 2018, pp. 70-112 and the ECtHR's case-law cited therein. 
of preventive measures, in particular, of provisional custod ${ }^{60}$. Moreover, the analysis has shown that the rights of victims as procedural parties, being elaborated in legal codes, are not accompanied by effective practical implementation. Therefore, the protective rights of alleged vulnerable victims, particularly victims of sexual offences, pose a greater threat to the rights of a defendant ${ }^{61}$.

This is particularly important given the fact that the catalogue of such offences has been expanded in Germany as a result of the 2016 reform of the Criminal Code $^{62}$, and in Poland, the Act on the Amendment of the Criminal Code, adopted on 13 June 2019, significantly increased the severity of penalties for sexual offences ${ }^{63}$.

Therefore, one can distinguish the following aspects in which the ECtHR takes account of the interests of victims of crimes:

1) in the area of the right to a fair trial, if the victims pursue civil claims under a criminal procedure,

2) in the area of the so-called positive obligations of the state to provide the victims with criminal-law protection, which entails granting them with procedural rights,

3) through certain restriction of the defendant's right to defence due to the necessity of protection of victims-witnesses ${ }^{64}$.

However, a review of the ECtHR's case-law does not allow reconstruction of a coherent victim rights protection system, since the interests of victims in the area of obtaining of substantive criminal-law and procedural protection are only considered by the Court on the basis of the proportionality principle if they do not excessively restrict the defendant's right to a fair trial.

A brief analysis of the Directive 2012/29/EU and the CJEU's case-law concerning the Framework Decision 2001/220 allows to conclude that the EU law acts under analysis are also intended to provide the victims with, above all, rights of protective nature, including application of special protective measures towards some of them.

${ }^{60}$ Cf. C. Kulesza, Konflikt między prawami pokrzywdzonego i oskarżonego w perspektywie 10 lat ewolucji polskiego procesu karnego - zarys problemu, [in:] Artes serviunt vitae, sapientia imperat. Proces karny sensu largo - rzeczywistość $i$ wyzwania. Księga jubileuszowa Profesora Tomasza Grzegorczyka z okazji 70. urodzin, eds. J. Kasiński, A. Małolepszy, P. Misztal, R. Olszewski, K. Rydz-Sybilak, D. Świecki, Warszawa 2019, pp. 53-70.

${ }^{61}$ Cf. A. Kruse, E. Schmitt, J. Hinner, [in:] Forschungsprojekt Belastungen von Opfern in Ermittlungsverfahren Forschungsbericht, 2017, https://weisser-ringstiftung.de/sites/default/files/domains/ weisser_ring_stiftung/downloads/wrsforschungsberichthp_1.pdf [access: 10.02.2020], pp. 79-91.

${ }_{22}$ Cf. M. El-Ghazi, Das Schicksal der , sexuellen Handlung “ nach der Reform des Sexualstrafrechts, „Strafverteidiger“ 2018, vol. 4, DOI: https://doi.org/10.1515/stv-2018-380405, pp. 250-255.

${ }^{63}$ The President sent this act on 28 June 2019 to the Constitutional Tribunal.

${ }^{64}$ Cf. M. Wąsek-Wiaderek, Międzynarodowe akty prawne jako źródto praw pokrzywdzonego i świadka w procesie karnym, [in:] System Prawa Karnego Procesowego, vol. 1: Zagadnienia ogólne, ed. P. Hofmański, Warszawa 2013, p. 82 ff. 
However, the exercise of the rights of victims of crimes, both in the area of criminal-law protection (the decisive stage of the trial) and the right to protection from victimization, particularly important in case of victims who require particular protection (vulnerable victims), must take place, as reserved by Directive 2012/29/ EU, "without prejudice to the right to defence". Similar reservations are found in other EU acts preceding Directive 2012/29/EU, establishing the rights of specific groups of victims (in particular, in Directive 2011/36/EU of 5 November 2011 on preventing and combating trafficking in human beings, as well as Directive 2011/93/ EU of 13 December 2011 on combating the sexual abuse and sexual exploitation of children). However, it should be noted that no binding document on the rights of victims has been adopted so far on the global forum, while on the European forum, due to lack of political consensus, no specific efforts intended to develop a protocol to the ECHR concerning those issues have been taken. In view of the above, it should be concluded that the procedural rights of defendants still have priority over the rights of victims, which is an obvious consequence of inclusion of the former into the catalogue of human rights ${ }^{65}$.

Finally, the results of a survey conducted in 2019 among law students of the Faculty of Law of the University of Bialystok should be mentioned. The subject of the study was to examine how Polish students perceive the role of a victim in the origin of an offence as well as their evaluation of the Criminal Code regulations referring to the rights of victims in this context. Two hundred and twenty seven students have been subjected to the research using a survey questionnaire, including 101 students of law and 126 students of criminology. The survey included 170 women $(74.9 \%)$ and 57 men $(25.1 \%)$. As part of the research, students were asked, among others, to assess the impact of the protection procedure of interrogation of adult victims of rape as provided for in Article 185c (as it stood prior to the amendment of 19 July 2019) on the defendant's right to defence. Almost half of the students of law and criminology, i.e. 112 (49.4\%), answered positively, while only 31 answered negatively (13.7\%). However, it is worth noting the high number of students, i.e. $84(37 \%)$, although they knew the regulation of Article 185 of the Criminal Code, did not take a stand on its impact on the defendant's right to defence.

In turn, the answers to the question concerning the relevance of granting of prosecutorial powers to an injured party (a victim) who has contributed to perpetration of a crime were distributed quite evenly: 95 (41.9\%) of the survey have spoken in favour of such powers of the injured party, whereas an opposite view was expressed by $94(40.4 \%), 38(16.7 \%)$ students had no opinion in this regard ${ }^{66}$.

${ }^{65}$ E. Bieńkowska, Wiktymologia, Warszawa 2018, pp. 241-244.

${ }^{66}$ All research results are presented in monograph: C. Kulesza, Wiktymologia procesowa, Białystok 2020, pp. 31-47. 


\section{REFERENCES}

\section{Literature}

Bala A., Victims and Retributive Responses at the European Court of Human Rights: Scrutinizing the Coercive Dimension of Reparations, "iCourts Working Paper Series" 2019, no. 155, DOI: https://doi.org/10.2139/ssrn.3337689.

Berg J., [in:] Strafprozessordnung. Mit GVG und Nebengesetzen. Kommentar, ed. J.P. Graf, München 2010.

Beukelmann S., [in:] Strafprozessordnung. Mit GVG und Nebengesetzen. Kommentar, ed. J.P. Graf, München 2010.

Cooper A., Quas J.A., Cleveland K.C., The Emotional Child Witness: Effects on Juror Decision-making, "Behavioral Sciences \& the Law" 2014, vol. 32(6), DOI: https://doi.org/10.1002/bsl.2153.

Bieńkowska E., Wiktymologia, Warszawa 2018.

Budyn-Kulik M., Komentarz do art. 148, [in:] Kodeks karny. Komentarz aktualizowany, ed. M. Mozgawa, LEX/el. 2020.

Carre Z., The Failure of $R$ v. Killick to Give Victims of Crime a Voice, "North East Law Review" 2016, vol. 4.

Dearing A., Justice for Victims of Crime. Human Dignity as the Foundation of Criminal Justice in Europe, Vienna 2017.

Dudka K., Praktyka stosowania nieizolacyjnych środków zapobiegawczych w polskim procesie karnym, Warszawa 2015.

Dudka K., Artymiak G., Sytuacja pokrzywdzonego w procesie karnym ze szczególnym uwzględnieniem oskarżyciela positkowego i powoda cywilnego, Warszawa 2012.

El-Ghazi M, Das Schicksal der ,, sexuellen Handlung “ nach der Reform des Sexualstrafrechts, „Strafverteidiger" 2018, vol. 4, DOI: https://doi.org/10.1515/stv-2018-380405.

Ellison L., Munro V.E., Better the Devil You Know? 'Real Rape' Stereotypes and the Relevance of a Previous Relationship in (Mock) Juror Deliberations, "International Journal of Evidence \& Proof" 2013, vol. 17(4), DOI: https://doi.org/10.1350/ijep.2013.17.4.433.

Emmerson B., Ashworth A., Macdonald A., Choo L.-T., Summers M., Human Rights and Criminal Justice, London 2012.

Fansher A., Carmen R.V. del, Child as Witness: Evaluating State Statutes on the Court's Most Vulnerable Population, "The Children Legal Rights Journal” 2016, vol. 36.

Gobert J.J., Victim precipitation, “Columbia Law Review” 1977, vol. 77(4),

DOI: https://doi.org/10.2307/1121822.

Gorf C., [in:] Strafprozessordnung. Mit GVG und Nebengesetzen. Kommentar, ed. J.P. Graf, München 2010.

Hoyano L.C., Striking a Balance between the Rights of Defendants and Vulnerable Witnesses: Will Social Measures Directions Contravene Guarantees of a Fair Trial?, "Criminal Law Review" 2001, no. 12.

Hörnle T., The New German Law on Sexual Assault and Sexual Harassment, "German Law Review" 2017, vol. 18(6), DOI: https://doi.org/10.1017/S2071832200022355.

Huber M., [in:] Strafprozessordnung. Mit GVG und Nebengesetzen. Kommentar, ed. J.P. Graf, München 2010.

Juy-Birman R., The German system, [in:] European Criminal Procedures, eds. M. Delmas-Marty, J.R. Spencer, Cambridge 2008. 
Kebbell M., O'Kelly C.M.E., Gilchrist E., Rape Victims' Experiences of Giving Evidence in English Courts: A Survey, "Psychiatry, Psychology and Law" 2007, vol. 14(1), DOI: https://doi.org/10.1375/pplt.14.1.111.

Klip A., On Victim's Rights and Its Impact on the Rights of the Accused, "European Journal of Crime, Criminal Law and Criminal Justice" 2015, vol. 23(3),

DOI: https://doi.org/10.1163/15718174-23032067.

Kruse A, Schmitt E., Hinner J., [in:] Forschungsprojekt Belastungen von Opfern in Ermittlungsverfahren Forschungsbericht, 2017, https://weisser-ringstiftung.de/sites/default/files/domains/ weisser_ring_stiftung/downloads/wrsforschungsberichthp_1.pdf [access: 10.02.2020].

Kulesza C., [in:] Kodeks postepowania karnego. Komentarz, ed. K. Dudka, Warszawa 2018.

Kulesza C., Directive 2012/29/EU of 25 October 2012 establishing minimum standards on the rights, support and protection of victims of crime, [in:] Improving Protection of Victims'Rights: Acces to Legal Aid, eds. P. Wiliński, P. Karlik, Poznań 2014.

Kulesza C., Fair trial for a victim of crime? - European standards and Polish experience, Paper presented at the $16^{\text {th }}$ International Symposium of the World Society of Victimology "Victims and Victimization: Moving Towards an International Victimology", Hong Kong, 10-14 June 2018, www.cityu.edu.hk/ss_wsv2018/about/files/Conc/Cezary\%20Kulesza\%20-\%20Fair\%20trial\%20 for\%20victims.pdf [access: 20.02.2020].

Kulesza C., Konflikt między prawami pokrzywdzonego i oskarżonego w perspektywie 10 lat ewolucji polskiego procesu karnego - zarys problemu, [in:] Artes serviunt vitae, sapientia imperat. Proces karny sensu largo - rzeczywistość i wyzwania. Księga jubileuszowa Profesora Tomasza Grzegorczyka z okazji 70. urodzin, eds. J. Kasiński, A. Małolepszy, P. Misztal, R. Olszewski., K. Rydz-Sybilak, D. Świecki, Warszawa 2019.

Kulesza C., Wiktymologia procesowa. Zagadnienia wybrane, Białystok 2020.

Kulesza C., Kużelewski D., Victim-offender mediation as an alternative to the criminal justice system in Poland, "Temida" 2018, vol. 21(1), DOI: https://doi.org/10.2298/TEM1801003K.

Kulesza C., Kużelewski D., Znaczenie reformy kodeksu postępowania karnego dla efektywności mediacji, [in:] Mediacja w prawie, eds. J. Czapska, M. Szeląg-Dylewski, Kraków 2014.

Kulesza C., Starzyński P., [in:] Dyrektywa Parlamentu Europejskiego i Rady ustanawiajaca normy minimalne w zakresie praw, wsparcia i ochrony ofiar przestępstw. Komentarz, eds. E. Bieńkowska, L. Mazowiecka, Warszawa 2014.

Kużelewski D., Protection of the aggrieved party's rights in the appeal proceedings, [in:] Fairness of the New Model of Polish Criminal Appeal Proceedings in the Context of Delivered Research, ed. C. Kulesza, Bialystok 2019.

Kühl K., Heger M., Strafgesetzbuch. Kommentar, München 2016.

Lach A., Postępowanie dowodowe w sprawach karnych $w$ świetle orzecznictwa strasburskiego, Warszawa 2018.

Maisch H., Schueler-Springorum H., Procedural Victimology and Its Contribution to Victimological Knowledge, [in:] Victimology: A New Focus, vol. 3: Crimes and Justice, eds. I. Drapkin, E. Viano, Toronto-London 1975.

Meyer-Gossner L., Schmitt B., Strafprozessordnung. Mit GVG und Nebengesetzen, München 2017.

Norman H.R., Adult rape victims need protection too: The application of closed circuit television and the exception from maryland v. craig to adult rape victim testimony, "Washburn Law Journal" 2016, vol. 55(3).

Peter M., Measures to protect victims in German criminal proceedings. A summary with special focus on the key points of the Second Victims'Rights Reform Act, https://www.unafei.or.jp/publications/ pdf/RS_No81/No81_13VE_Peter.pdf [access: 20.05.2020]

Prusek M., Utajnienie zeznań świadka w procesie karnym a realizacja konstytucyjnej zasady proporcjonalności, „Palestra” 2017, no. 7-8. 
Rerick P.O., Livingston T.N., Davis D., Rape and the Jury, [in:] Handbook of Sexual Assault and Sexual Assault Prevention, eds. W. O’Donohue, P.A. Schewe, Cham 2019.

Roxin C., Schünemann B., Strafverfahrensrecht, München 2009.

Schroeder F.Ch., Strafprozessrecht, München 1997.

Schünemann B., Protection of children and other vulnerable victims against secondary victimisation: Making it easier to testify in Court, "Era Forum" 2009, vol. 9,

DOI: https://doi.org/10.1007/s12027-009-0130-7.

Skazania prawomocne - z oskarżenia prywatnego - dorośli - w latach 2013-2017, Warszawa 2018, https://isws.ms.gov.pl/pl/baza-statystyczna/opracowania-wieloletnie [access: 20.02.2020].

Skorupka J., [in:] Kodeks postępowania karnego. Komentarz, ed. J. Skorupka, Warszawa 2020.

Spencer J.R., "Rape shields" and the right to fair trial, "Cambridge Law Journal" 2001, vol. 60(3), DOI: https://doi.org/10.1017/S0008197301241191.

Sprawozdanie $z$ działalności powszechnych jednostek organizacyjnych prokuratury $w$ sprawach karnych za rok 2018, https://pk.gov.pl/wp-content/uploads/2019/04/PG_P1K.pdf [access: 25.01.2020].

Statistisches Bundesamt, Berlin 2019, www.destatis.de [access: 20.01.2020].

Stellungnahme des Deutschen Anwaltvereins durch die Task Force „Anwalt für Opferrechte“ unter Beteiligung des DAV-Ausschusses Strafrecht zum Referentenentwurf des Bundesministeriums der Justiz und für Verbraucherschutz Entwurf eines Gesetzes zur Stärkung der Opferrechte im Strafverfahren, Berlin 2014.

The Victims'Rights Directive 2012/29/EU. European Implementation Assessment. Study, European Parliamentary Research Service, Brussels, December 2017, www.europarl.europa.eu/RegData/ etudes/STUD/2017/611022/EPRS_STU(2017)611022_EN.pdf [access: 20.01.2020].

Trocha O., Udziat dzieci w postępowaniu karnym - wyniki badań, obserwacje, rekomendacje, „Dziecko krzywdzone. Teoria, badania, praktyka" 2013, vol. 12(4).

Van Dijk J.J.M., Victim's Rights: A Right to Better Services or a Right to Active Participation, [in:] Criminal Law in Action. An Overwiev of Current Issues in Western Societies, eds. J.J.M. Van Dijk, J. Hoffmans, J. Schuttle, S. Stoliwijk, Arnhem 1986.

Wąsek-Wiaderek M., Międzynarodowe akty prawne jako źródło praw pokrzywdzonego i świadka w procesie karnym, [in:] System Prawa Karnego Procesowego, vol. 1: Zagadnienia ogólne, ed. P. Hofmański, Warszawa 2013.

Weiner B., [in:] Strafprozessordnung. Mit GVG und Nebengesetzen. Kommentar, ed. J.P. Graf, München 2010.

Wróbel W., [in:] Kodeks karny. Część ogólna. Komentarz, ed. A. Zoll, vol. 1, Kraków 2007.

Zmodyfikowane typy przestępstw w teorii i praktyce sądowej, eds. J. Giezek, J. Brzezińska, Warszawa 2017.

\section{Legal acts}

Directive 2012/29/EU of the European Parliament and of the Council of 25 October 2012 establishing minimum standards on the rights, support and protection of victims of crime, and replacing Council Framework Decision 2001/220/JHA (OJ EU L 315/57). 


\section{Case law}

\section{CJEU}

Case C-507/10, X(21 December 2011), ZOTSiS, 2011/12C/I-14241-14284.

Case C-205/09, E. Eredics, M.V. Sápi (21 October 2010), ECR I-10231.

Case C-404/07, G. Katz v. I.R. Sós (10 July 2008), ZOTSiS 2008/10/I-7607.

Case C-467/05, Giovanni Dell'Orto (28 June 2007), ECR I-05557.

Case C-483/09, Gueye and Salmerón Sánchez (15 September 2011), ECR-I-10231.

Case C-38/18, Massim Gambin and Shpetim Hyka (19 July 2019), https:/eur-lex.europa.eu/legal-content/EN/TXT/HTML/?uri=CELEX:62018CJ0038\&from=EN [access: 20.04.2020].

\section{ECtHR}

N.K. v. Germany (complaint no. 59549/12), 26 July 2018.

Przydziat v. Poland (complaint no. 15487/08), 24 May 2016.

Wilczyński v. Poland (complaint no. 35110/10), 12 September 2017.

\section{Polish Supreme Court}

Judgement of the Supreme Court of 12 February 2019, II KK 291/18, Legalis.

\section{STRESZCZENIE}

Celem artykułu jest zbadanie konfliktu między prawami pokrzywdzonych i oskarżonych w niemieckim i polskim systemie wymiaru sprawiedliwości na tle orzecznictwa trybunałów europejskich. Analizą objęto dwie możliwości zaistnienia powyższego konfliktu w procesie karnym: 1) w sferze poznawczej, obejmujące udowadnianie winy bądź niewinności oskarżonego, oraz 2) w sferze decyzyjnej, obejmującej wszczęcie postępowania karnego, stosowanie środków zapobiegawczych i wyrokowanie. Główna teza artykułu głosi, że przyznanie pokrzywdzonemu w polskim i niemieckim systemie wymiaru sprawiedliwości nie tylko praw ochronnych, lecz także statusu aktywnej strony procesowej, rodzi w obu wyżej wskazanych sferach procesu karnego większe ryzyko takiego konfliktu niż np. w systemie anglosaskim, gdzie ofiara przestępstwa występuje tylko jako świadek. Jednakże badania przytoczone w opracowaniu wskazują, że rozbudowanym kodeksowym uprawnieniom proceduralnym pokrzywdzonych jako stron procesowych (law in books) nie towarzyszy ich efektywne wykorzystywanie w praktyce procesowej (law in action). Dlatego też większe niebezpieczeństwo dla praw oskarżonego, składających się na zasadę rzetelnego procesu z art. 6 Europejskiej Konwencji Praw Człowieka, stwarzają prawa ochronne domniemanych ofiar wrażliwych na pokrzywdzenie, szczególnie ofiar przestępstw seksualnych. Rozważania w niniejszym artykule potwierdzają także tezę, że nadal pierwszeństwo przed prawami ofiar mają prawa procesowe oskarżonych, co oczywiście wynika z wpisania tych ostatnich do katalogu praw człowieka zawartego w Europejskiej Konwencji Praw Człowieka.

Slowa kluczowe: konflikt praw; ofiara przestępstwa; oskarżony; ETPC; TSUE 